\title{
Struktúra és communitas
}

\author{
Szubkulturális problémamegoldó tudás egy alternatív gimnáziumban
}

\author{
SZENTESI BALÁZS ${ }^{1}$
}

\begin{abstract}
ABSZTRAKT
Az írás egy budapesti alternatív iskola, a „Diákház” belső diskurzusában megjelenő szubkulturális és iskolai/intézményi értelmezések kapcsolatát mutatja be. Két eltérő értelmezési kerethez tartozó értelmezéseket és gyakorlatokat, amelyek párhuzamosan, egymásba fonódva jelennek meg a diákházi kommunikációs színtéren. Ez hozzájárul egy olyan problémamegoldó felkészültség/tudás létrejöttéhez, amely külön egyik értelmezési keretben sem jelenik meg. Ebben a diskurzusban a különbözöség, deviancia, marginalitás, ellenállás vagy a communitas szubkulturális megnyilvánulásai, illetve a tudás, önállóság, felelősségvállalás és az iskolai hierarchikus struktúra megnyilvánulásai hol egymással szembeállítva, hol egymást erősítve jelennek meg. A diskurzusban létrejövő tudást a Diákház fel tudja használni a (korábban iskolaelhagyó) diákok intézményen belül tartásához, a diákok pedig saját érvénytelenség-élményük csökkentéséhez. Így a Diákház a két ellentétes társadalmi állapotot, a communitast és a struktúrát képes a saját hasznára fordítani.
\end{abstract}

KULCSSZAVAK: communitas, struktúra, szubkultúra, iskola, iskolai kimaradás, érvénytelenség

\section{ABSTRACT}

\section{Structure and communitas. Subcultural problemsolving knowledge in an alternative high school}

The paper describes the relationship between subcultural and school/institutional interpretations in the inner discourse of an alternative school (the 'Diákház') in Budapest. Interpretations and practices, that belonging two different interpretive frameworks, appear simultaneously and intertwined in the Diákház communication scene. This contributes to problem-solving capacities/knowledge that individually do not appear in either of the two. In this discourse, the subcultural manifestations of difference, deviance, marginality, resistance or communitas, and the manifestations of knowledge, autonomy, responsibility and the hierarchical structure of the school sometimes appear in opposition, sometimes in reinforcement to each other. The knowledge formed in the discourse can be used by the Diákház to keep (formerly drop-out) students within the institution, and by the students to reduce their own feeling of invalidity. In this way, the Diákház is able to use the two opposite social states, communitas and structure, to its own benefit.

KEYWORDS: communitas, structure, subculture, school, drop-out students, invalidity

${ }^{1}$ Budapesti Corvinus Egyetem Társadalmi Kommunikáció Doktori Iskola, balazs.szentesi@gmail.com. 


\section{KÖZELKÉP - Tanulmányok}

\section{Bevezetés}

Jelen írás egy készülő disszertáció metszete², amelyben egy budapesti alternatív gimnázium, a Diákház ${ }^{3}$ belső diskurzusát elemzem. A disszertáció központi témája az érvénytelenség élménye, a (más iskolákból kimaradó) diákházi diákok közös problémája, valamint azok a szubkulturális gyakorlatok és értelmezések, amelyeket a Diákház intézményesített formában tart fönn. Utóbbiakon keresztül az iskola olyan problémamegoldó felkészültséget (tudást) tesz elérhetővé a diákjai számára, amelyet használhatnak az érvénytelenség problémájának kezelésében.

A Diákház egy Budapesten közel 30 éve működő alapítványi fenntartású, tandíjmentes gimnázium, egy ún. „második esély” iskola, ahol a felvétel elsőszámú kritériuma a jelentkező félbemaradt középiskolai karrierje. Múködését tekintve a Diákház több szempontból eltér a legtöbb „hagyományos” és „alternatív” oktatási intézménytől. Egyrészt a diákság szociokulturálisan igen sokszínű (ennek oka a tandíjmentesség, illetve a tanárok szociális, etnikai, vallási, kulturális alapú szelekció elkerülésére irányuló igyekezete). Másrészt a Diákház pedagógiai rendszere nélkülözi a legtöbb hagyományos középiskolai formalitást, fegyelmező és pedagógiai eszközt, amelyek helyett személyre szabott bánásmóddal és követelményekkel, a diákok mentori támogatásával, alternatív formális és nem formális fegyelmező technikákkal dolgoznak. Továbbá figyelemreméltó a diákok és tanárok egy részére jellemző szubkulturális vonzódások intenzív megnyilvánulása, és egyes, az ifjúsági/zenei szubkultúrákra jellemző múködésmódok jelenléte az iskolai színtéren. Utóbbiak fontos szerepet játszanak abban, hogy a más oktatási intézményekben gyakran kezelhetetlen diákok képesek együtt dolgozni a diákházi tanárokkal, és az iskola sikeresen teljesíti célját, a másutt lemaradó fiatalok támogatását és érettségiztetését.

Az alábbiakban a disszertációban megjelenő elméleti koncepciót és a kutatás eredményeit foglalom össze. Ennek során kitérek a diákok és a Diákházban megjelenített problémáik bemutatására, a Diákház intézményi/iskolai és szubkulturális működésmódjára, valamint a diákházi diskurzus főbb témáira. Azt igyekszem leírni, hogy az iskolai hierarchikus struktúra és a szubkulturális communitas (egyenrangúság) élményének párhuzamos fenntartása során hogyan jelenik meg az érvénytelenség megoldására alkalmas tudás.

\footnotetext{
${ }^{2}$ A tanulmány szövegét a disszertáció nagyjából 200 oldalából ragadtam ki, így egyes részkérdések részletes kifejtésére itt nincsen mód, ugyanakkor a teljes szöveg megszületése után, egy későbbi tanulmányban tervezem tisztázni őket.

${ }^{3} \mathrm{Az}$ iskola nevét a dolgozatban megváltoztattam.
} 


\section{KÖZELKÉP - Tanulmányok}

\section{Módszertan és elmélet}

A diákházi diskurzust 2004 és 2016 között több szakaszban, hosszan elnyúló terepmunka keretében vizsgáltam. A kutatást etnográfiai módszerekkel végeztem: elsősorban résztvevő megfigyeléssel, amelyet kiegészítettem félig strukturált interjúkkal, fotók, videó- és hangfelvételek készítésével, valamint az adatközlők által készített dokumentumok (fotók, videofelvételek, írásos anyagok), illetve online tartalmak (weboldalak, fórumok, közösségi oldalak bejegyzései) gyűjtésével. A kutatás főbb fázisai egy 2004-es közel féléves és egy 2011-2012-ben folytatott közel egyéves megfigyelés voltak. ${ }^{4} \mathrm{~A}$ főbb fázisok közötti időszakban és a második fázis után tartottam a kapcsolatot kulcsadatközlőimmel, valamint évente néhány alkalommal látogatásokat tettem a Diákházban és a diákházasok által szervezett külső rendezvényeken.

Az iskola területén és közvetlen környékén kívül kutattam más budapesti helyszíneken (pl. szórakozó- és vendéglátóhelyek, magánlakások), a fővároson kívül (pl. hétvégi ház, üdülőhely) vagy éppen utazás közben (vonaton, távolsági buszon, terepjáró platóján). Az adatgyűjtés során elsősorban a személyes interakciókat és más kommunikatív gyakorlatokat (pl. hirdetések, dekoráció, öltözet) rögzítettem, a tartalmi elemek mellett a metakommunikatív viselkedésekre is figyelve, leírtam továbbá időgazdálkodással és térkezeléssel kapcsolatos gyakorlatokat is. Igyekeztem érvényes megállapításokat tenni jellegzetes diákházi témákról, problematikákról, problémakezelési módokról, megnyilvánulási formákról és tanár-diák viszonyokról. Érdekelt a diákházasok iskolai karrierje, Diákházba kerülésük útja, szociokulturális hátterére, iskolához/formális intézményekhez/társadalomhoz való viszonyuk, szubkulturális kötődéseik (ezek kapcsán öltözködési stílusuk, zene- és egyéb fogyasztási szokásaik is). Különösen érdekeltek a diákok külső színterekről származó, az iskolai színtéren is megjelenített (ön)értelmezései (pl. punk, cigány, drogos, radikális jobboldali, hajléktalan), és az ezek kommunikálása és használata körül kialakuló (gyakran tréfák, viták, provokatív megnyilvánulások és konfliktusok formájában megjelenő) egyeztetések, alkudozások. Érdekeltek továbbá az iskolai hierarchikus viszonyok megjelenítésének formái is. A munka során a diákházi kulturális gyakorlatok sűrü leírását (Geertz 2001b) igyekeztem létrehozni. ${ }^{5}$

A kutatás kérdéseinek megfogalmazása és az adatok értelmezése során kommunikációs és kulturális antropológiai megközelítést alkalmaztam. Egyrészt a kommunikáció participációs elméletének (továbbiakban: PTC) abból az alaptételéből indultam ki, amely szerint a kommunikációban való részvétel valamilyen problémamegoldás során használható többletfelkészültség (tudás) hozzáférhetőségét biztosítja a problémamegoldó ágensek számára (Horányi 1999). Másrészt a kultúra, illetve in-

\footnotetext{
${ }^{4}$ Bár a disszertációban főleg a második kutatási fázis adatait dolgozom föl, a változások követése alapján a leírtak érvényessége kiterjeszthető a Diákház korábbi (és későbbi) időszakaira is.

${ }^{5}$ A kutatás módszertanáról részletesebben lehet olvasni tanulmányomban (Szentesi 2018).
} 


\section{KÖZELKÉP - Tanulmányok}

terkulturális kommunikáció interpretív és kritikai felfogásából, amelyben a kultúra a világról alkotott értelmezések hálójaként (Geertz 2001a) jelenik meg. A kommunikáció a kultúrát (egyúttal a résztvevők identitásait) megjelenítő és meghatározó konstrukciós gyakorlat (Carbaugh 2007), az interkulturális kommunikáció pedig egymással hierarchikus viszonyban álló (etnikai, nemi, szociális, szubkulturális vagy más alapon meghatározott) értelmezések (és a hozzájuk kapcsolódó identitások) küzdelme (Hall 1996, Martin - Nakayama - Carbaugh 2012). Ennek megfelelően a kommunikációs tevékenységet valamilyen probléma megoldására irányuló igyekezet részeként fogom fel, az interkulturális kommunikáció esetében pedig az eltérő diskurzusokhoz kapcsolódó értelmezések érvényesítését tekintem a központi problémának, illetve az eltérő színterekről származó, eltérő értelmezések találkozását mindig interkulturális kommunikációnak.

Célom a diákházi diskurzus hátterében álló problémamegoldó igyekezet tárgyának (a problémának) a megfogalmazása, valamint a diskurzusban való részvétel által elérhetővé váló, a probléma felismeréséhez és megoldásához hozzájáruló többletfelkészültség leírása volt. Az iskolára (általában véve) interkulturális kommunikációs színtérként tekintek, azaz úgy, mint különböző kulturális értelmezések és az értelmezési keretek ütköztetésének színterére. Így a vizsgált problémát (interkulturális) kommunikációs zavarként, a problémamegoldó kommunikációt pedig az értelmezések közös alakítására és ütköztetésére irányuló (kulturális) gyakorlatként fogtam fel.

A diákházi diákok jellemző, iskolaelhagyáshoz vezető problémáinak a bemutatásánál felhasználtam a serdülőkori krízis elméleteit (lásd később). A diákházi működés szubkulturális elemeinek és funkcióinak feltárásához a szubkultúra-kutatás nemzetközi irányzatainak irodalmára és néhány fontosabb hazai munkára támaszkodtam. ${ }^{6}$

${ }^{6}$ A szubkultúra elméleti keretként először a chicagói iskolában jelenik meg, mint a csoportos problémamegoldás példája. Eszerint a tágabb társadalmi rendszer normáihoz illeszkedő problémamegoldást megvalósítani nem tudó/akaró emberek csoportja az előbbitől eltérő közös normarendszer (szubkultúra) kialakításával hoz létre megoldást (Cohen 1955). A szubkultúra-kutatás második nagy hullámát azok a birminghami iskolához (Centre for Contemporary Cultural Studies - CCCS) kötődő kutatások alkotják, amelyek a specifikus helyek, kapcsolatok, társas események és (munkásosztályi) identitás köré szerveződő szubkultúrákat az uralkodó kultúrának való ellenállás szimbolikus formáinak tekintik (Clarke et al. 1976). Az ellenállás „mágikus” (valós megoldást nem nyújtó) eszközei a középosztályi, fogyasztói kultúrából átemelt és saját jelentéssel felruházott öltözködési és zenei elemek, nyelvezet, rítusok (Cohen 1980). Az 1980-as években az osztályhelyzet, az identitás és a szubkultúra közötti szoros kapcsolat CCCS-ben alkalmazott koncepciójával, illetve a kutatások többségét jellemző „külső” nézőponttal szemben jelennek meg a szubkultúrák tagjainak belső átélését megragadni igyekvő posztszubkultúra-kutatások. Ebben a megközelítésben az eredetiség és státusz keresésének keretet adó szubkultúrák tagjai a tudás, viselkedés és felhalmozott javak szubkulturálisan felismert formáit magába foglaló - a kulturális tőkéhez (Bourdieu 1999) hasonló - szubkulturális tőke alapján létrehozzák a fősodor/szubkultúra, illetve kommerciális/ alternatív dichotómiákat, és felértékelik magukat, mint az „átlagemberekkel” szemben autonóm, egyéni ízléssel rendelkező személyeket. (Thornton 1995) A szubkulturális stílus az egyéniség kifejeződése, 


\section{KÖZELKÉP - Tanulmányok}

Munkám témája, terepe, módszertana és elméleti háttere szerint több diszciplináris és kutatási területet érint. Legszorosabban a szubkultúra-kutatási hagyományhoz kapcsolódik, azon belül is leginkább a valamikori szubkulturalistákból lett kutatók résztvevő megfigyeléssel végzett posztszubkultúra-kutatásaihoz (Thornton 1995, Bennett 2003, Hodkinson 2002). Az etnográfiai módszertan és a kultúra koncepciójának együttes alkalmazása miatt ugyanakkor a kulturális (szimbolikus és interpretív) antropológiához is kapcsolható, még ha különbözik is az elsősorban nemzeti/etnikai/nyelvi keretek között értelmezhető idegen társadalmak kultúráinak vizsgálatára irányuló jellegzetes antropológiai kutatásoktól. Az iskola mint terep elsősorban egy jól definiálható keretet biztosított számomra ehhez a munkához, amely (bár nem az iskola pedagógiájára irányult) pedagógiai szempontból értelmezhető megállapításokhoz is vezetett. Ebben a tekintetben kutatásom kapcsolható az ethnography of education kutatási területhez - amelyet Mészáros (2017) pedagógiai etnográfiának fordít -, azon belül is a szűkebb területet lefedő, zömében antropológusok által végzett anthropology of education (pedagógiai antropológia) kutatásokhoz.

Munkám újdonságértéke a szubkultúra-kutatási hagyomány szempontjából részben a (poszt)szubkulturális értelmezési keret és kutatási módszertan alkalmazása egy iskolai közösség vizsgálatára. Másrészt, ellenben a szubkultúra szakirodalommal - ahol a szubkulturális gyakorlatokat szokásosan az intézményesített, formális struktúrával szembeállítva mutatják be - én azt mutatom be, hogy a szubkulturális gyakorlatok (kiemelten a „másság” megkonstruálásában rejlő problémamegoldó potenciál) hogyan tarthatók fönn/használhatók föl intézményesített keretek között. Kulturális antropológiai szempontból munkám a tartós szociális rendszerként múködtetett normatív communitas (Turner 2002) egy példájának a bemutatása. Pedagógiai antropológiai szempontból a hazai oktatási rendszerben korábban nem létező eszköz múködésének a leírása és kulturális elemzése. Annak bemutatása, hogy a diákházi diskurzust belülről feszítő és hajtó ellentmondás, a struktúra és a communitas élménye közötti állandó egyensúlyozás hogyan teszi fenntarthatóvá az iskolai múködést, a hagyományos iskolai formalitások, gyakorlatok és hatalmi viszonyok nélkül.

önmagáért, a megjelenésért fontos. A szubkulturalisták nem azonosulnak egyértelmű csoportmeghatározásokkal, inkább a felületes szubkulturális kötődések, a szubkultúrák közötti átjárások jellemzők (Muggleton 2002). A fentiek mellett munkámban a hazai szubkultúra-kutatásban meghatározó Rácz József munkáira támaszkodom, aki az 1980-as évek magyarországi szubkultúrái kapcsán az intézményesített közegből kikerülő/kivonuló fiatalok státusz- és szerepvesztését, illetve a szubkultúra szociális és védő funkcióit emeli ki (Rácz 1998). 


\section{KÖZELKÉP - Tanulmányok}

\section{A színtér résztvevői: diákok és tanárok ${ }^{7}$}

A kutatás második szakasza idején (2011-2012) a Diákházba beiratkozott (de az iskolában nem feltétlenül megjelenő) 107 diáknak nagyjából a 70\%-ával és a „stábot" (tanárok munkacsoportja) alkotó kilenc tanárral találkozhattam. ${ }^{8} \mathrm{~A}$ döntően 17-23 éves korosztályba tartozó, többnyire a fóvárosban lakó, kisebb részben a fővárosi agglomerációból vagy egy-egy esetben messzebbről bejáró diákok mind más középfokú oktatási intézményekben kezdték, majd megszakították tanulmányaikat. A Diákházba leginkább a tanárok által a Diákház segítségére rászorulónak, tanulásra motiváltabbnak, „érettebbnek” és a diákházi viszonyok között működőképesebbnek ítélt fiatalok kerültek be, de a tanárok gyakran tettek kivételeket is az előbbi szempontok tekintetében.

Legtöbbjükre jellemző a stabil családi háttér hiánya (pl. bántalmazó, elhanyagoló szülők, egy vagy mindkét szülő hiánya) és a negatív iskolai tapasztalatok (pl. verbális vagy fizikai konfliktusok iskolatársakkal, tanárokkal, marginalizálódás), emellett megjelenek szorongások, önértékelési zavarok, illetve az anyagi bizonytalanság is. A diákok szociokulturális szempontból (pl. szüleik iskolai végzettsége, társadalmi osztálya, státusza vagy saját családi és anyagi hátterük, életkörülményeik, pályaorientációjuk, etnikai és kulturális hátterük, ideológiai elkötelezettségeik, nemi identitásuk és vonzódásuk szerint) igen sokszínű csoportot alkottak. Ugyanakkor jellemző volt bizonyos periférikus társadalmi kategóriák, devianciák és a depriváció jelenléte (többek között állami gondozott, korai anyaságot vállaló, családfenntartó, fogyatékkal vagy részképesség-zavarral élő, pszichés problémákkal kezelt, önsértő, drog- és alkoholfogyasztó vagy kisebb szabálysértésekben résztvevő fiatalok). A diákság tagjai között találkozhatunk különböző ifjúsági szubkultúrák - többek között punk, rapper, hippi, gót, skinhead, rocker - képviselőivel is.

A tanári stábot három 40-es évei közepén járó „ősdiákházas” és hat később csatlakozott 30 és 40 év körüli tanár alkotta. Ők azok, akik napi rendszerességgel, nagy óraszámban foglalkoznak a diákokkal és mentorálják is őket. Többen a diákházi munkájukat megelőzően vagy azzal párhuzamosan hagyományosabb iskolában is tanítottak, illetve páran „alternatív” iskolákból érkeztek. Rajtuk kívül hetente néhány alkalommal óraadó és gyakorló tanárok is megjelennek az iskolában, akiknek a tevékenysége az oktatásra korlátozódik.

Hasonlóan a diákok egy részéhez, a tanároknak is vannak fiatalabb vagy jelenkori szubkulturális kötődéseik (pl. underground), de amíg a tanárok esetében ez inkább a zenei ízlésben (néhányuk esetében aktív zenélésben) nyilvánult meg, a diá-

\footnotetext{
${ }^{7}$ Itt és a további fejezetekben a disszertáció azonos témájú fejezeteinek rövid összefoglalását adom, amelyek megfelelnek a kutatás fókuszában álló fő kérdésköröknek.

${ }^{8}$ Rajtuk kívül találkoztam még az iskolai adminisztrátorral, két hospitáló és több óraadó tanárral, az iskolai „mindenessel”, illetve szülőkkel, könyvelőkkel, egyéb külső munkatársakkal, segítő szakemberekkel, látogatókkal és az iskola környékén járókkal.
} 


\section{KÖZELKÉP - Tanulmányok}

koknál külső stíluselemek (ruha- és hajviselet, testékszerek, tetoválások) is utaltak rá. Ugyancsak a diákokhoz hasonlóan a tanároknak a hagyományosabb iskolákról általában negatív tapasztalataik vannak. Az erről szóló történeteikben a hierarchikus viszonyok merevsége, a munkatársak és diákok távolságtartó viselkedése jelenik meg, vagy csak egyszerűen a hagyományos rendszerbe való beilleszkedés képtelensége. Többen a már korábban, közép- vagy felsőfokú tanulmányaik során szerzett negatív élményeiket is olyan tényezőkként említik, amelyek az alternatív iskolai karrier felé irányították őket. Továbbá, mind a diákokra, mind a tanárokra jellemző, hogy kihangsúlyozták egymástól és az „átlagemberektől” való különbözőségüket, egyénként vagy a Diákház tagjaként átélt marginális társadalmi pozíciójukat, és (elsősorban a diákok) egyfajta pozitív „másságként” felfogott „devianciájukat”.

\section{A diákok problémái: serdülőkori krízis, kommunikációs zavarok, érvénytelenség}

Az iskola elhagyásához vezető tényezők sokfélék lehetnek, de a diákházi diákok mindegyikénél megjelennek a serdülőkori krízis állapotai, következményei vagy rizikófaktorai. A következőkben ezeket kapcsolatba hozom a hagyományos iskolai színtereken megjelenő kommunikációs zavarokkal, és bemutatom, ahogyan később, már a Diákházban a diákok marginalizálódásának, iskolából való kihullásának, illetve mindannyiuk közös problémájának a forrásaként értelmezik őket. A Diákházban ez a közös probléma a „másság” lesz, vagy ahogyan én nevezem, az érvénytelenség.

Eseti/akcidentális krízis akkor alakul ki, ha a fontos életcélok elérését külső okok akadályozzák, és a helyzetet a szokásos problémamegoldó módszerekkel nem sikerül leküzdeni (Caplan 1961). A fejlödési/normatív krízis viszont szükségszerúen, az életkori szakaszok (csecsemő, kisgyermek, óvodás, iskolás, serdülő stb.) közötti átmenetek időszakaiban alakul ki. Minden szakaszhoz sajátos kihívások, problémák és a megoldásukhoz szükséges kompetenciák társulnak. A krízisen való túljutás feltétele az új életszakaszhoz tartozó problémamegoldó készségek elsajátítása (Erikson 1950). Jacobson (1979) krízismátrix fogalma hosszabb (akár évekig tartó) kritikus időszakot jelöl, amelyben az egyén sérülékenyebb és a kritikus élethelyzetek nagyobb eséllyel vezetnek eseti krízishez.

A fejlődési szakaszok közül a biológiai, pszichológiai és szociális változásokkal terhelt serdülőkor a legválságosabb időszak. Feladata az identitás újraformálása, stabilizálása, önálló, teherbíró személyiség kialakítása, amelynek sikertelensége többek között szerepkonfúzióhoz, beilleszkedési problémákhoz, pszichés tünetekhez vezethet. A dolgozatban a felnőttkorra jellemző kihívások megoldásához szükséges kompetenciák kialakulatlanságával járó sérülékenységet összekapcsoltam a diákházi diákokra gyakran jellemző állapotokkal, problémákkal és problémamegoldási módokkal. Ilyenek pl. az önérvényesítés, önértékelés, alkalmazkodás problémái, 


\section{KÖZELKÉP - Tanulmányok}

szociális gátlás, családi/környezeti háttér rizikófaktorai (pl. válások, betegségek, halálozások a családban, bántalmazó vagy elhanyagoló családok, állami gondozottság, rossz szociális körülmények), iskolai teljesítmény zuhanása, marginalizálódás, a szülői/társadalmi elvárások, a társadalmi betagozódás szimbólumainak elutasítása, normák megkérdőjelezése, provokatív magatartás, feltűnő öltözék, hajviselet, testékszerek, tetoválások, trágárság, veszélykeresés, teljesítmény kerülése, alkohol- és drogfogyasztás, szabályszegések, önsértő magatartás, öngyilkossági kísérletek, és egyebek (Holmes - Rahe 1967, Gyenge 2014, Hajduska 2015). A serdülőkori krízishez kapcsolódó jelenségek közül egy vagy több megjelenik szinte minden diák tapasztalataiban és önképében, különösen a korábbi iskolákban vagy a kortárs csoportban átélt marginalitás élménye, a szociális elszigetelődés, illetve az autoritásszimbólumokkal való szembefordulás a jellemző.

Az itt leírt jellemzők és állapotok a diákok hagyományos iskolai színterein kommunikációs zavarokhoz vezettek. ${ }^{9} \mathrm{Az}$ iskolai kommunikációs zavaroknak azok az esetei foglalkoztattak, amelyekben a kommunikáció értelmezési kerete tisztázatlan, illetve ahol a tanár és a diák között küzdelem folyik a kontextus definiálásáért. Az érdekelt, hogy a kontextus definiálása a résztvevők (jelen esetben a diákok) problémáinak megoldását segítő vagy hátráltató értelmezések fenntartásához járul-e hozzá, és (ahogyan a diákházasok is teszik) a hagyományos iskolai értelmezési keret viszonylagos merevségének koncepciójára építettem a diákok közös problémájának definiálását.

A diákházi diskurzusban a diákok problémái mind a hagyományos iskolai színtéren érvényes elvárásokhoz nem illeszkedő esetekként, vagy másképpen a legitim módon kommunikálható tartalmak és a diákok kommunikál(hat)atlan értelmezései és problémái közötti különbségnek, ${ }^{10}$ a diákok „másságának” a példáiként jelennek meg. A különbözőség ténye kerül középpontba, nem pedig a különbözőség (szociális, kulturális, etnikai, életkorbeli, képességbeli stb.) dimenziói, így téve a „másságot” a nagyon különböző problémákkal és identitásokkal érkező diákok közös problémájává.

${ }^{9}$ A kommunikációs zavart a kommunikáció matematikai elmélete alapján az információ torzulásaként definiálom (Shannon 1986), azon belül pedig a jelentésértelmezés szemantikai és hatékonysági szinten jelentkező problémáival foglalkozom (Weaver 1986). A jelentésértelmezés mindig a metakommunikatív értelmezési kerethez kötött (Bateson 1955), és ahogyan lehetetlen nem kommunikálni, úgy a mindenkori kommunikációs kontextus definiálásában is lehetetlen nem részt venni. Ezért a kommunikáció interakcionista elmélete alapján a kommunikációt mindig az értelmezési keret kölcsönös alakításának, a jelentésértelmezés zavarát pedig egyúttal az értelmezési keret definíciós problémájának is tekintem (Watzlawick - Beavin - Jackson 2009).

${ }^{10}$ Ez a különbség megfelel a PTC megközelítésében a problémát alkotó különbségnek. A PTC problémának nevezi „azt a kritikus különbséget, ami az adott ágens valamely alkalommal való állapota és egy számára ugyanakkor kívánatos állapot között (...) fennáll, amennyiben ezt az ágens felismeri" (Horányi 2007: 246). Itt a „»kritikus« éppen arra a különbségre utal, ami már problémamegoldó viselkedést vált ki az adott alkalommal az adott ágensben" (Horányi 2007: 247). A problémamegoldás nem feltétlenül a különbség megszüntetését jelenti, hanem a kritikus (problémamegoldó aktivitást kiváltó) szint alá csökkentését. 


\section{KÖZELKÉP - Tanulmányok}

Ezt a közös problémát én az érvénytelenség problémájának nevezem. Ehhez Linehan (2010) elméletét vettem alapul, aki az érvénytelenítő hatású szociális környezet lélektani következményeiről ír. Ez a környezet az egyén tapasztalatait, önmagáról, szándékairól, céljairól alkotott interpretációit hibásnak, érvénytelennek láttatja. Pszichés zavarokhoz vezethet, ha az egyén nem képes elhagyni vagy megváltoztatni az érvénytelenítő környezetet.

A „másság” diákházi diskurzusban közösként megjelenő problémájából és Linehan (2010) érvénytelenség-koncepciójából kiindulva, de a PTC elméleti-fogalmi keretében definiáltam az érvénytelenség problémáját. Itt az érvénytelenség az ágens felkészültségeinek alkalmazhatatlanságát, az ágens által felvetett problémák és értelmezések legitimitásának hiányát jelenti egy adott intézményi színtéren. Az intézményi színterek definitív sajátossága (az ágensek egyéni felkészültségei alapján alakuló kommunikációs színterektől eltérően) egy a priori konstitutív alap megléte, amely kódolja a színtéren legitimnek tekinthető kommunikációs viselkedésre (pl. jelentésadásra, értelmezésre) vonatkozó szabályokat. Ezzel meghatározza a kommunikatív problémafelismerés és -megoldás lehetőségeit is, illetve biztosítja a színtéren megjelenő értelmezések legitimálásának eljárásait is (Pete - P. Szilczl 2007)11.

A diákházi diákok közös tapasztalata, hogy a hagyományos iskolai színtereken nem tudták érvényesíteni saját felkészültségeiket sem bizonyos problémáik (lásd serdülőkori krízis) kommunikálására, sem azok megoldására, illetve ezek a színterek eleve nem kínáltak erre legitim lehetőségeket. Ilyenek híján jellemzően megpróbálkoztak más (pl. családi, kortárs, szubkulturális) színtereken érvényes értelmezések érvényesítésével. A színtéridegen értelmezések és az identitások reprezentációinak azok a fajtái, amelyek megbontják az iskolai értelmezési keret koherenciájának és megkérdőjelezhetetlenségének érzetét, veszélyesek a színtér legitimitására, és a legtöbb iskolában érvénytelenítésre kerülnek. Az értelmezési keret meghatározásáért, a saját értelmezések érvényesítéséért folytatott küzdelemben alulmaradó diákok strukturálisan alacsonyabb, illetve az iskolában marginálisabb pozíciókba kényszerülnek ${ }^{12}$ vagy akár önként választják azokat.

A diákok felkészültségeinek elutasításával azok a külső színterek is leértékelődhetnek, amelyekről beemelték őket, és amelyeken még legitimnek számítottak (pl. punk frizura vagy tetoválás egy szubkulturális közösségben), valamint velük együtt az ezekhez a színterekhez kapcsolódó önértelmezéseik is. Vagyis akkor beszélek az érvénytelenség problémájáról, ha az nem csupán egy-egy helyzetre vonatkozik, hanem az ágens önképét is érinti, amelyben szerepe van az iskolán kívüli színtereken zajló diskurzusoknak, és az érvénytelenítő kommunikáció hatásával való megküzdés képességének is. Tehát nem (feltétlenül) a diákok hagyományos iskolai színtereit

11 Az érvénytelenség participációs elméletre alapozott koncepciójáról részletesebben lehet olvasni tanulmányomban (Szentesi 2019).

${ }^{12}$ Vö. Philips 2005, Carbaugh 2005. 


\section{KÖZELKÉP - Tanulmányok}

tekintem az érvénytelenség forrásának, csupán kiemelem, hogy ezek a színterek nem segítették, hanem hátráltatták őket a problémáik kezelésében, ezzel hozzájárulva saját érvénytelenségük (sokszor más színtereken kialakult) élményének megerősödéséhez, általánossá válásához, illetve az iskolaelhagyáshoz.

\section{Iskolai és szubkulturális működésmód}

Dolgozatom egyik kiinduló állítása, hogy a Diákházi kommunikációban párhuzamosan két értelmezési keret jelenik meg, amelyeket a hozzájuk tartozó kommunikációs viselkedésekkel, illetve azok funkcióival együtt iskolai és szubkulturális múködésmódnak nevezek. Ez a kettősség a diákok érvénytelenség-problémájának kezelésében fontos szereppel bír.

Az iskolai múködésmódot a formálisan rögzített vagy rögzítetlen, de pedagógiai/ nevelési céllal strukturált szabályok, gyakorlatok és eszközök leírásán keresztül mutatom be. A diákházi működést a hagyományos iskolai formalitások hiánya jellemzi. Nem léteznek a fegyelmezés/számonkérés hagyományos formái és a hozzájuk kapcsolódó szankciók (pl. bejárási kötelezettség, feleltetés, intő, osztály, „osztály vigyázz", ülésrend, magázódás és hasonlók). A diákok és a tanárok együtt beszélgetnek, étkeznek, dolgoznak, játszanak a tanáriban, a kiscsoportos, differenciált, kooperatív formában vezetett tanórák alatt bárki szabadon megoszthatja gondolatait, helyet változtathat, étkezhet, távozhat, és jobbára bárki bemehet bármelyik tanórára. Minden diáknak van egy mentora a tanárok között, akivel közösen kidolgozza a saját egyéni haladási ütemét, és megoszthatja iskolai vagy iskolán kívüli problémáit. Az egyéni haladási tervet, illetve a diák vállalásait a felmerülő problémák kapcsán szerződésekben rögzítik. A Diákházat a közös döntések felelősségén osztozó stáb irányítja, amelynek funkciói közé tartozik a diákokról gyưjtött információk megosztása, megoldáskeresés az iskola és a diákok problémáira, a pedagógiai munka elméleti és módszertani hátterének biztosítása, valamint a tanárok védelme a segítő munkából adódó pszichés következményektől. A diákok a „diákstábon” képviselhetik/érvényesíthetik igényeiket egymással vagy a tanárokkal/iskolával szemben. ${ }^{13}$

Az iskolai mindennapok formalizálatlanságától élesen elkülönülnek a vizsgák ${ }^{14}$ hagyományos iskolai formalitásai (pl. frontális ülésrend, különültetés, távolságtartóbb, visszafogott kommunikáció), amelyet a diákok némelyike nehezen visel. A formalitások legerősebben az érettségi vizsgán jelennek meg, amelyet a diákok független érettségi bizottság előtt tesznek. A vizsgaidőszakok után visszatérnek a

${ }^{13}$ A diákstáb nem csupán formalitás, a tanárok tényleg kíváncsiak a diákok véleményére, amelyet figyelembe vesznek a döntések meghozatalakor, ill. vannak döntések, amiket a diákok hozhatnak meg. Emellett időnként a diákok és tanárok is használják az iskolán belüli konfliktusaik nyílt kezelésére is.

${ }^{14}$ A vizsgákat a tanulmányi időszakok végén tartják, a tanévet kettő, három vagy négy szakaszra bontották (ez változott az évek során). 


\section{KÖZELKÉP - Tanulmányok}

szorgalmi időszakok alig formalizált viszonyai. Az intézményi múködés alkalmi eseményeinek (évnyitó, ballagás, bankett) formális elemeit viszont a tanárok igyekeznek minimálisra szorítani, vagy gúnyt űzni belőlük.

A szabályozás formalizálatlansága nem vezet anarchikus viszonyokhoz. Lehetőséget ad nem formális szabályozó és fegyelmező eszközök (figyelem megvonása/ megadása, egyezkedések, egyéni beszélgetések) alkalmazására, és segít bevonni a formális renddel szembehelyezkedő diákokat az iskolai munkába, segít felkelteni motivációjukat, mentesíti őket az iskolai szankcióktól való szorongásaiktól. A létező formalitások (szerződések, stábülések) nagyobbrészt a szabályok rugalmas, személyre szabott alkalmazásának lehetőségét biztosítják, másrészt a diákok elért eredményeinek más intézményi színterekre való átkonvertálhatóságát (lásd erősen formalizált vizsgák és független vizsgabizottság előtt tett érettségi).

A szubkulturális múködésmód elemeit a szubkulturális diskurzusok és a diákházi diskurzus egyes gyakorlatai, koncepciói közötti analógiák megvonásával írtam le. Egyrészt a diákházi múködés jellegzetességeit összevetettem a szubkultúra-kutatás irányzataiban felbukkanó koncepciókkal, mint pl. a szimbolikus deviancia ${ }^{15}$ (Cohen 1955, Anderson 2014), a védelmező provokáció ${ }^{16}$ (Cohen 1955), az ellenállást kifejező stílus (Cohen 1972, Hebdige 1979), és az individualista, „elitista” elhatárolódás az „átlagtól” (Becker 1966, Thornton 1995). Másrészt Haenfler (2013) több szubkultúra-megközelítést figyelembe vevő szubkultúra-definíciójából indultam ki, amely szerint a szubkultúra olyan viszonylag diffúz szociális hálózat, amely közösen osztott identitással, megkülönböztető jelentésekkel felruházott elképzelésekkel, gyakorlatokkal és tárgyakkal, valamint a konvencionális(nak tekintett) társadalommal szembeni ellenállás vagy ahhoz képest létrejövő marginalitás érzetével jellemezhető.

A Diákházban (a diffúz szociális hálózatot leszámítva) kimutathatók a fenti kitételeknek részben vagy egészben megfeleltethető elemek. Bár a diákházasok nemigen számoltak be közös identitásról, és inkább az egymás közötti különbségeket szeretik hangsúlyozni, mind megkülönböztetik magukat az „átlagemberektől” és kifejeznek közösen osztott ideákat. Hasonlóan, nem jellemezhetők ugyan közös (stílusban, zenei irányultságban vagy szabadidő eltöltésében tükröződő) megkülönböz-

${ }^{15}$ Az anyagi okokra visszavezethető deviáns viselkedés és a szimbolikus deviancia közötti különbségtétel Cohennél (1955) jelenik meg. Az utóbbi a középosztályi érvényesülési lehetőségektől elzárt (bűnözői szubkultúrákhoz csatlakozó) munkásosztályi fiataloknak a konform megoldásokkal és társadalommal való szembenállását fejezi ki. Anderson (2014) a szimbolikus deviancia fogalmát kiterjeszti azokra, akik önmagában (a fehér, középosztályi, heteroszexuális, férfi standardtól való) különbözőségük miatt deviáns, kívülálló státuszba kerülnek (pl. feketék, homoszexuálisok), amire válaszul az ellenállást és a „másság” ünneplését választják, pozitív identitáselemet kreálva belőle.

${ }^{16}$ Cohen (1955) védelmezô provokációnak nevezi, amikor a szubkulturalisták a csoporton kívüliekből igyekeznek haragot, ellenséges érzületeket kiváltani, és ezekre hivatkozva felmentik magukat a feléjük érvényes morális kötelezettségeik alól. 


\section{KÖZELKÉP - Tanulmányok}

tető jelentésekkel, de külön-külön sokuk zenei és stílusválasztásai, illetve aktivitásai utalnak szubkulturális vonzódásaikra, valamint a közös iskolai tevékenységek között is találhatók kifejezetten nem-normatív jelentéseket felvonultató aktivitások (pl. szubkulturális szórakozóhelyeken tartott bankettek). Az előzőkhöz képest sokkal egyértelműbben kimutathatók a „konform társadalommal” szembeni ellenállás formái (pl. iskolarendszer, intézmények, formális hierarchia, tanárok, iskolai szabályok elutasítása, ellenzése, megkérdőjelezése, ignorálása). Ugyanígy nagyon jellemzők a marginalitás megnyilvánulásai, részben társadalmi perifériák formájában (pl. hajléktalanok, állami gondozottak, kisebbségek, bevándorlók, LMBTQ személyek), részben a „másként gondolkodás” kinyilvánításában.

A szubkulturális müködéshez sorolom továbbá a communitas élményét. Turner (2002) az átmeneti rítusok van Gennep (2007) által leírt hármas felosztása ${ }^{17}$ alapján mutatja be a középső, liminális fázisban megjelenő communitas állapotát, amely a benne részesülők alázatosságával, bajtársi és egalitárius érzéseivel, a közöttük fennálló rang- és státuszbeli különbségek eltűnésével vagy homogenizálódásával jellemezhető. A communitas az egyének közötti egyenrangúság, a strukturálatlan vagy kezdetlegesen strukturált és viszonylag differenciálatlan közösség, együttesség élménye, amely a hierarchikus rendszerbe rendeződő, strukturált társadalmi lét ellentéte. Ott jelenhet meg, ahonnan a struktúra visszavonul, így pl. a struktúra határain (a marginalitásban) és a struktúra „alatt” (az alsóbbrendűségben). Turner (2002) a rituális liminalitás mellett más társadalmi jelenségekben is azonosítja a communitast, egyebek között a státuszokhoz kötött társadalmi rendből „kiiratkozó” beatnik és hippi szubkultúrákban. A communitast mások is leírják a szubkulturális összejövetelek jellemzőiként (Thornton 1995, Muggleton 2002, Gelder 2005, Rill 2006, Rohrer 2014). A Diákházban a communitas tetten érhető pl. a térkezelés közösségi sajátosságaiban vagy a közvetlen tanár-diák viszonyokban (pl. tegeződés, közös étkezés, játék, zenélés).

\section{A diákházi értelmezések tematikus csoportjai}

A disszertációban igyekeztem bemutatni a diákházi kommunikáció tipizálható tartalmi elemeit. Aszerint elemeztem őket, hogy hogyan járulnak hozzá az egyik vagy másik fenti működésmódhoz, esetleg mindkettőhöz.

A diákházi diskurzusban megjelenő értelmezések néhány főbb tematikus csomóponthoz sorolva felrajzolnak egyfajta diákházi normarendszert. Ezek az értelmezé-

${ }^{17}$ Van Gennep (2007) három, minden átmeneti rítusban megjelenő fázist ír le: az elválasztó fázist (amely az egyént vagy csoportot elválasztja korábbi társadalmi helyzetétől), a határhelyzeti vagy liminális fázist (amelyben az egyénre vagy csoportra a korábbi helyzetéhez kapcsolódó társadalmi elvárások már nem, az újak pedig még nem érvényesek) és a befogadó fázist (amelyben a rítus alanyait a közösség újra befogadja, de már egy újabb társadalmi helyzetben). 


\section{KÖZELKÉP - Tanulmányok}

sek (az esetlegesen megjelenő egyéb értelmezésekkel szemben) ismétlődő módon, egymáshoz kapcsolódva szövik át az iskolai kommunikációt, függetlenül a kommunikációs helyzettől és a kommunikáció tárgyától. Egy tanórai verselemzés során éppúgy megfigyelhetők, mint a tanárok vagy diákok szünetekben folytatott társalgásaiban. A főbb témákhoz tartozó értelmezések prezentálása normatív elvárásként is megjelenik a diákházi diskurzusban.

A diákházi diskurzust meghatározó értelmezések egyik központi csoportját másság-diskurzusnak nevezem. Azokat a megnyilvánulásokat és értelmezéseket sorolom ide, amelyek a diákházasok és a Diákház „másságáról”, illetve a „másság” társadalmi helyéről szólnak. A másság-diskurzust a (1) különbözőség és sokszínűség, (2) deviancia, (3) marginalitás, (4) ellenállás további témáira bontom.

(1) A különbözőség és sokszínűség témájához a diákházasok egymástól való különbözőségét, és a különbözőséghez, sokszínűséghez való pozitív viszonyát megjelenítő megnyilvánulások tartoznak (pl. a megkülönböztető stílust felértékelő megnyilvánulások vagy a diákházasok közötti különbségeket összemosó kijelentések kerülése). Ezekből kirajzolódik a diák- és tanárgenerációk váltakozásától függetlenül jelenlévő, az individuális különbségeket, jellemzőket messzemenőkig toleráló diákházi értékrend. (2) A deviancia témájába a diákok valódi és szimbolikus devianciájára (Cohen 1955, Anderson 2014) utaló megnyilvánulásokat sorolom. Előbbi értelemben inkább a tanárok használják a diákok rászorultságáról vagy a személyre szabott bánásmód szükségességéről szóló állításaik alátámasztására (pl. amikor a diákok iskolai karrierjének megakadásait és a mögötte álló okokat említik). A diákoknál inkább pozitív értelemben, a társadalmi normáknak való tudatos, büszkén vállalt ellenszegülésként jelenik meg. (3) A marginalitásról szóló megnyilvánulások magukba foglalják a negatív marginalitást, amely a többségi kirekesztő viselkedés következményeként jelenik meg, valamint egyfajta „elitista” eltávolodást a konvencionálistól, a társadalom kicsinyes, szűk látókörü, kispolgári, „,konformista” tagjaitól. Előbbi megjelenik pl. az iskolai és kortárs csoportokból kiszoruló, bántalmazott diákok beszámolóiban, utóbbi az „átlagembereket” és a „strigulázós” világot lesajnáló megnyilvánulásokban és a tanároknak a Diákház perifériás pozíciójára utaló megjegyzéseiben. Ez a pozíció a tanárok szerint a Diákház egyediségéből, a más (hagyományos és alternatív) iskoláktól való pedagógiai távolságából, illetve (lévén az iskola térítésmentes) az anyagi lehetőségeik szűkösségéből és következésképp alacsony érdekérvényesítő képességükből fakad. (4) Az ellenállás témájába sorolom a „konformista fösodort" jelképező vagy a „többségi” társadalom szabályait betartatni igyekvő személyek bosszantását, megbotránkoztatását, a velük való konfliktusokat, vagy az ezekről szóló beszámolókat. Ezek amellett, hogy a serdülőkori autoritáskonfliktus egyik formájának tekinthetők (Hajduska 2015), védelmező provokációként (Cohen 1955) múködve segítenek fenntartani a Diákház és a külvilág közötti szembenállás képzetét. (Ide tartozik pl. amikor egy tanár a diákokkal együtt provokálta a más iskolákból érkező, szűk látókörűnek ítélt megfigyelőket.) A másság-dis- 


\section{KÖZELKÉP - Tanulmányok}

kurzus a különbözőség, marginalitás és szembenállás szubkulturális koncepcióihoz (Haenfler 2013) hasonló értelmezések elérhetővé tételével a Diákház szubkulturális müködésmódjához kapcsolódik.

A másság-diskurzus témái mellett hangsúlyos még az önállóság és felelősségvállalás témája. Ide tartoznak a diákok tanulmányi és egyéb iskolai ügyekkel (pl. bejárás, felkészülés) kapcsolatos döntési szabadságára, a döntésekkel járó és saját iskolai előrehaladásukkal kapcsolatos felelősségükre utaló megnyilvánulások. Ide sorolom továbbá azokat a megnyilvánulásokat is, amelyekkel a tanárok a diákokat bátorítják, hogy vegyék igénybe a számukra fontos ügyek képviseletére rendelkezésre álló lehetőségeket, fórumokat (pl. petíciók, diákstáb) akár diáktársaikkal, akár a tanárokkal vagy az iskolával szemben is. Az önállóság és a felelősségvállalás témájába tartozó megnyilvánulások a Diákházban egyszerre jelenítik meg a felnőttes viselkedésre irányuló társadalmi elvárást, és a hagyományos iskolai kötöttségekkel való leszámolást, így az iskolai és a szubkulturális működésmódhoz egyaránt kapcsolódnak.

Leírom továbbá a tudás témáját, amelyhez a tudás, képzettség, okosság és a társadalmi státusz közötti kapcsolatot megjelenítő (olykor nagyon didaktikus) megnyilvánulások tartoznak. Ez a kapcsolat egyrészt negatív színben tünik föl a más iskolákban tanító és a tudás kizárólagos jogához ragaszkodó tanárokról, a tudáshoz kapcsolódó státuszukkal visszaélő személyekről szóló történetekben, másrészt pozitív színben, a tényleges tudást a kiüresedő formális hierarchiával szembeállító megnyilvánulásokban. A tudás témája az elutasított társadalmi struktúrát és a struktúra visszásságaival szembeni állásfoglalást egyaránt megjeleníti, így az önállóság és felelősségvállalás témájához hasonlóan az iskolai és a szubkulturális működésmódhoz is kapcsolódik. ${ }^{18}$

${ }^{18}$ A disszertációban kitérek a diákházi nyilvánosság fenti értelmezéseket megjelenítő gyakorlataira is. Részletes bemutatásukra itt nincs mód, ezért csupán röviden felsorolom őket. (1) A személyes megjelenés és a testkezelés stílusa. (2) Egyes szubkulturális (legkifejezettebben a punk) színterek gyakorlataira hasonlító dekoráció (pl. leselejtezett és újrafelhasznált tárgyakból kialakított kollázsok és eszközök, társadalomkritikai élú montázsok) és street-art elemek. (3) Fontos diákházi értelmezéseket példabeszédszerűen megjelenítő elmesélt történetek (pl. a státuszok kiüresedő rendjét a tudással, emberséggel szembeállító történetek). (4) A communitas élményhez hozzájáruló pár fős tanár-diák beszélgető-körök. (5) A deviáns viselkedéseket, tulajdonságokat (pl. drogfogyasztás, női homoszexualitás, marginalitás) karikírozott, eltúlzott formában megjelenítő, rögtönzött performatív aktusok. (6) Az Albert-napon (a Diákház ünnepe) bemutatott rövid dramatikus játékok és táncbemutatók a státuszmegfordítás (Turner 2002) karneváli formáihoz (ld. pl. Bahtyin 2002) hasonló elemekkel. (7) Az iskolai diskurzus szempontjából nem központi, de az iskolai és szubkulturális működéshez kapcsolható tartalmakat egyaránt megjelenítő online felületek. 


\section{KÖZELKÉP - Tanulmányok}

\section{Az érvénytelenség diákházi „megoldása”}

Mint az elméleti részben írtam, az iskolai színtereket olyan interkulturális kommunikációs színtérnek tekintem, amely a különböző diskurzusok (résztvevői) közötti küzdelmeknek ad teret. Ezek a küzdelmek az értelmezési keret meghatározásáért, a résztvevők saját értelmezési kereteinek alkalmazásáért folynak (Hall 1996). Ez a megközelítés lehetővé tette, hogy az iskolai értelmezési keretbe külső (szubkulturális, etnikai, vallási, nemi, szociális vagy egyéb alapon definiált) színterekről beemelt értelmezéseket egyaránt (kulturális) identitások megjelenítésének tekintsem. Ez azt is jelenti, hogy (a Diákházhoz hasonlóan) a legkülönfélébb szociokulturális jelenségekhez kapcsolódó kommunikációt egységes keretben tudtam kezelni, és az értelmezések legitimálásának vagy elutasításának eseteit összefüggésbe tudtam hozni a kommunikációban résztvevők önértelmezésében megjelenő érvényesség/érvénytelenség élményével. Így be tudtam mutatni, hogy az iskolában az értelmezési keret definiálására irányuló próbálkozások hogyan válnak a saját érvényesség megteremtéséért vívott harc ütközeteivé, és a diákok korábbi iskolákban elvesztett „csatái” hogyan vezetnek az (identitás szintjén is megjelenő) érvénytelenség érzetéhez, marginális, alacsonyabb rendű állapotokhoz. Továbbá, így megragadhatóvá vált az értelmezési keret közös alakítására épülő diákházi gyakorlat haszna a szociokulturálisan sokszínű diákság, és a „másságból” eredő érvénytelenség-élmény problémájának kezelésében.

Amíg a hagyományos iskolai színtereken a diákok színtéridegen értelmezéseit gyakran nem legitimálták, addig a diákházi színtéren a formális szabályozás hiánya miatt a diákok viselkedése és értelmezései (az olyan szélsőséges eseteket leszámítva, mint verekedés, alkohol- vagy drogfogyasztás) formálisan nem minősülhetnek illegitimnek. Ez lehetőséget ad a diákok számára, hogy alkudozzanak a tanárokkal a külső (sokszor szubkulturális) színterekről beemelt értelmezéseik legitimációja felett. Az alkudozás során a tanárok az iskolai és a diákok által prezentált (ön)értelmezések között egyensúlyozva igyekeznek teret adni a diákoknak a megmutatkozásra. Ide tartoznak többek között a „radikális” fogalmának történelmi vagy skinhead szubkulturalista értelmezése feletti vita egy tanórán, vagy az ellenállást, marginalitást reprezentáló stílus (pl. punk haj vagy élő patkány viselése) és témák (pl. drog, homoszexualitás megtárgyalása) megjelenítésének határait feszegető próbálkozások. A diákok (ön)értelmezései nem mindig nyernek legitimitást az iskolai színtéren, de az alkudozásokban így is a világ egy lehetséges leírásaként jelenhetnek meg, hozzájárulva az érvényesség élményének kialakulásához.

Ahogyan bemutattam, szubkulturális elemek nem csak kívülről beemelt értelmezésekként jelennek meg az iskolai diskurzusban, hanem az iskolai múködésmód gyakorlatai mellett alapvető részei a diákház működésének. Megjelennek a kommunikáció témáiban és a hozzájuk kapcsolódó értékítéletekben, valamint a szubkulturális közösségeket idéző communitas élmény formájában is. 


\section{KÖZELKÉP - Tanulmányok}

A szubkulturális és intézményi/iskolai gyakorlatok, funkciók és értelmezések párhuzamos fenntartásával a Diákház egyszerre teszi hozzáférhetővé diákjai számára a státuszemelkedés szubkulturális és formális intézményi módját. Az előbbi forrása a másság-diskurzus, amelyben a diákok „mássága” értékként és csoportképző tényezőként jelenik meg, nem az érvénytelenség, hanem az érvényesség élményéhez járulva hozzá. Az iskolai működésmód pedig formális intézményi keretek között tartja a szubkulturális múködést, amely a diákok viselkedésének szabályozásával lehetséges (eszközei az imént említett alkudozások, a diákok saját vállalásaira épülő szerződések, a tanárok kölcsönös tudását, segítő eszközeit és kommunikációs stratégiáit biztosító stáb és a mentorrendszer). Ez teszi lehetővé, hogy a szubkulturális működésből származó „haszon” elősegítse a formális intézményi rendszerben is érvényesnek tekintett státuszemelkedést (érettségi bizonyítvány megszerzése).

A két egymással ellentétes társadalmi állapot, a communitas (a diákházasok közötti rangbéli egyenlőség) és a struktúra (a tanárok és diákok közötti hierarchikus viszonyok) (Turner 2002) egyidejű átélhetősége állandó feszültséget teremt a diskurzusban, amely mozgásban is tartja azt. Az iskola irányításához szükséges a hierarchikus állapotok fenntartása, amelyeket viszont a formális struktúrának ellenálló diákok elől el is kell rejteni. Az ebből keletkező feszültség oldásának bevett gyakorlatai alakultak ki (a communitas-élmény határait kitapogató, feszegető provokatív megnyilvánulások, a hierarchiával szembeni nyílt állásfoglalás, a tanár státuszát megkérdőjelező gondolatok őszinte kifejezése, valamint a hierarchikus viszonyokat felszínre hozó tréfák). A szubkulturális és az iskolai múködés, a communitas és a struktúra kölcsönösen érvényesítik egymást. A struktúra egyfajta normatív communitast ${ }^{19}$ hoz létre, azaz fenntarthatóvá teszi a communitast, amely így nem csak (a szubkulturalisták összejöveteleihez hasonló) spontán helyzetekben élhető át, hanem az iskolai színtér keretein belül hosszabb ideig, visszatérő és kiszámítható módon. A communitas élménye és a hierarchia retorziók nélküli megkérdőjelezésének lehetősége pedig elfogadhatóvá teszi a diákok számára az iskolai hierarchikus struktúrát, így a struktúrán való kívülállás élményéne ${ }^{20}$ átélése válik a strukturális pozícióemelkedéshez vezető úttá.

A másság-diskurzus hatással van a diákházasok identitáskonstrukciós, illetve társadalmi kategorizációs gyakorlataira. Itt a „másság” nem csak jellemzőként vagy az iskolai kimaradásra vonatkozó általános magyarázóelvként jelenik meg, hanem az önmeghatározás elemévé is válik (vagy sok diákházasnál már eleve az volt).

${ }^{19}$ A Diákházban (a vizsgaidőszakot leszámítva) lényegében a normatív communitas jelenik meg, amely a (pl. hippik happeningjein, rave-partikon stb. létrejövőhöz hasonló) spontán communitas állapotát igyekszik hosszabb ideig fenntartani, de valójában maga is a struktúra részévé válik, mivel a cél érdekében erőforrásokat kell mozgósítania és megszerveznie, így a csoport tagjainak ellenőrzése is szükségessé válik (Turner 2002).

${ }^{20}$ A struktúra jelenléte miatt valós kívülállásról nincsen szó, csupán az élményéről. 


\section{KÖZELKÉP - Tanulmányok}

Ebben a diskurzusban a „hagyományos” vagy „konform” (iskolai) világ, valamint az előbbitől különböző és élesen elkülönülő saját világ társadalmi kategóriáin keresztül teremtődik meg a Diákház mint közösség. ${ }^{21}$ Közösségként - bár Haenfler (2013) definíciója alapján szervezettsége miatt nem tekinthető szubkultúrának - a szubkulturális közösségek Rácz (1998) által leírt szociális és védő funkcióit is ellátja. Ezek a kirekesztettség-élmény csökkentése, önértékelés javítása, a társadalom leértékelésével szemben biztonságot nyújtó, közös háttértudással rendelkező csoport alakítása. Ezek hozzájárulnak, hogy a diákházasok számára az individualizáció és a „valahova tartozás" egyszerre legyen átélhető.

A diákházi „megoldás” további fontos összetevője, hogy a diskurzusban a különbözőség, ellenállás, marginalitás megjelenítésének eszközei (pl. stílus) mellé sorolódnak az okosság vagy tudás és a felelősségvállalás is. Ezzel a Diákház a diákokat a „valódi” devianciák helyett a deviancia ártalmatlanabb (és „okosabb”) szimbolikus megnyilvánulásaival (Cohen 1955, Anderson 2014) való azonosulás felé tereli.

\section{Összegzés}

Írásomban készülő doktori disszertációm koncepcióját és fontosabb eredményeit foglaltam össze. Az írás a „Diákházban”, egy budapesti alternatív gimnáziumban végzett, időben hosszan elnyúló, több éves, etnográfiai módszerekkel végzett kutatásra épült. Munkám során kulturális antropológiai és kommunikációs megközelítést alkalmaztam. A PTC alapján a kommunikáció lényegét a problémamegoldáshoz való hozzájárulásban látom (Horányi 1999). Az interkulturális kommunikáció interpretív és kritikai megközelítésében az iskolákat olyan interkulturális kommunikációs színtérnek tekintettem, amelyen a résztvevők eltérő értelmezési keretek alkalmazásával küzdenek egymással a saját értelmezéseik és egyúttal önmeghatározásaik érvényességéért (Hall 1996, Martin - Nakayama - Carbaugh 2012). Ez egyúttal az interkulturális színterek elsődleges problémája.

A diákházi diákok közös problémájának körülírásához felhasználtam a serdülőkori krízis elméletét (Erikson 1950), Linehan (2010) elméletét az érvénytelenítő kommunikáció káros hatásairól, és a PTC intézményi kommunikációs színterekről alkotott elméletét (Pete - P. Szilczl 2007). A serdülőkori krízishez kapcsolódó tünetekkel és állapotokkal (kiemelten marginalitással és az autoritásnak való szembeszegüléssel) jellemezhető, egy vagy több középiskolát félbehagyó diákok problémájaként az érvénytelenséget neveztem meg, azaz a saját (ön)értelmezéseik legitimálhatatlanságának tapasztalatát adott (itt a hagyományos iskolai) színtereken. Az érvénytelenség megoldásához használható specifikusan diákházi többletfelkészült-

${ }^{21}$ A szubkulturális kategorizáció diákházi működéséről részletesebben írok tanulmányomban (Szentesi 2003). 


\section{KÖZELKÉP - Tanulmányok}

séget (tudást) igyekeztem leírni, amelyhez szubkultúra elméleteket (Cohen 1955, Thornton 1995, Haenfler 2013, Rácz 1998) és Turner (2002) szubkultúra-szakirodalomban is felbukkanó communitas koncepcióját használtam.

A diákházi színtéren két múködésmódot azonosítottam, amelyeket iskolai és szubkulturális működésmódoknak nevezek. Az előbbihez az intézmény működtetése és a pedagógiai célok elérése érdekében alkalmazott értelmezéseket, gyakorlatokat és ezek funkcióit sorolom, az utóbbihoz a szubkultúrákra jellemzőként leírt értelmezések, gyakorlatok és ezek funkcióinak megjelenését a Diákházban. Kiemeltem a diákház iskolai gyakorlatainak formalizálatlanságát, amely nem vezet káoszhoz, ellenben lehetőséget teremt a szabályok, pedagógiai eszközök rugalmas alkalmazására, személyre szabására.

Leírtam a diákházi kommunikáció főbb tartalmi elemeit és összekapcsoltam az iskolai és/vagy szubkulturális múködésmódokkal. Egyrészt azt igyekeztem bemutatni, ahogyan a szubkulturális müködésmód elemei átszövik az iskolai életet, másrészt azt, ahogyan a két működésmód egymást kiegészítve, támogatva fejti ki hatását. Ez az érvénytelenség-élményre alkalmazható problémamegoldó felkészültség létrejöttének egyik kulcsmotívuma: az iskolai (hierarchikus) struktúra és a communitas (a strukturálatlan, rangbéli különbségek nélküli közösség) élményének párhuzamos fenntartása.

Ez a kettősség segít a diákoknak elfogadni az iskolai/intézményi kereteket és témákat (tudás, önállóság, felelősségvállalás). Egyúttal a szubkulturális témákat (különbözőség és sokszínűség, deviancia, marginalitás, ellenállás) magába foglaló másságdiskurzusban való részvétel teret ad a diákoknak a társadalommal szembeni ellenérzéseik kommunikálására is. Ebben a diskurzusban a diákok mássága értékké, az önmeghatározásuk részévé válik. A Diákház a szubkulturális csoportosulások szociális és védő funkcióit - önértékelés javítása, csökkenő kirekesztettség-élmény, biztonságot nyújtó, közös háttértudással rendelkező csoport (Rácz 1998) - nyújtja a diákjai számára.

Továbbá az iskolai működés formalizálatlansága lehetővé teszi, hogy saját (ön)értelmezéseiket beemeljék a közös iskolai diskurzusba és megküzdjenek azok érvényességéért. Szintén lényeges elem, hogy az iskolai színtérre beemelhető szubkulturális reprezentációk (pl. stílus) összekapcsolása az iskolai értelmezésekkel (pl. tudás) segítik a diákok azonosulását a deviancia szimbolikus formáival a valódi deviáns utak helyett.

Amint igyekeztem bemutatni, a Diákházban az iskolával, iskolarendszerrel való szembehelyezkedés motívuma képes az iskolából korábban kimaradó tanulókat oktatási intézményi keretben tartani. Ez (az alternatív, személyre szabott pedagógiai gyakorlatok mellett) a szubkulturális elemek és az iskolai funkciók párhuzamos fenntartásával válik lehetségessé. A kettő közötti egyensúly időnkét eltolódik az egyik vagy másik múködésmód javára, de ha a szubkulturális élmény és gyakorlatok 


\section{KÖZELKÉP - Tanulmányok}

túl hosszan előtérbe kerülnének, a Diákház már nem volna iskola, ha pedig az iskolai élmény és formalitások kerekednének fölül, már nem tudna együttműködni a diákokkal. Talán ez írja le legjobban a Diákházat, ez a folyamatos egyensúlyozás a communitas élménye és a struktúra között, amellyel képesek mindkét állapotot a maguk hasznára fordítani.

\section{Irodalom}

Anderson, T. L. (2014): Connections. Marginality, identity and music scenes. In: Anderon, T. L. (szerk.): Understanding deviance. Connecting classical and contemporary perspectives. London, Routledge, 507-516. https://doi.org/10.4324/9781315879635

Bahtyin, M. (2002): François Rabelais művészete. A középkor és a reneszánsz népi kultúrája. Osiris, Budapest.

Bateson, G. (1955): A theory of play and fantasy. A report on theoretical aspects of the project for study of the role of paradoxes of abstraction in communication. In: Kline, N. S. (szerk.): Approaches to the study of human personality. Psychiatric Research Reports 2, American Psychiatric Association, 39-51.

Becker, H. S. (1966): Outsiders. Studies in the sociology of deviance. New York, The Free Press.

Bennett, A. (2003): The use of 'insider' knowledge in ethnographic research on contemporary youth music scenes. In: Bennett, A. - Cieslik, M. - Miles, S. (szerk.): Researching youth. New York, Palgrave MacMillan, 186-199. https://doi.org/10.1057/9780230522466_12

Bourdieu, P. (1999): Gazdasági tőke, kulturális tőke, társadalmi tőke. In: Angelusz R. (szerk.): A társadalmi rétegződés komponensei. Budapest, Új Mandátum, 156177.

Caplan, G. (1961): An approach to community mental health. Tavistock Institute, London, https://doi.org/10.1016/S0033-3506(62)80082-1

Carbaugh, D. (2005): Cultures in conversation. Lawrence Erlbaum Associates, Mahwah.

Carbaugh, D. (2007): Cultural discourse analysis. Communication practices and intercultural encounters. Journal of intercultural communication research, 36(3): 167-182. https://www.doi.org/10.1080/17475750701737090

Clarke, J. - Hall, S. - Jefferson, T. - Roberts, B. (1976): Subcultures, cultures and class. A theoretical overview. In: Hall, S. - Jefferson, T. (szerk.): Resistance through rituals. Youth subcultures in post-war Britain. London, Hutchinson, 9-74. https://doi.org/10.4324/9780203224946 


\section{KÖZELKÉP - Tanulmányok}

Cohen, A. K. (1955): Delinquent boys. The culture of the gang. New York, Free Press.

Cohen, P. (1980): Subcultural conflict and working-class community. In: Hall, S. Hobson, D. - Lowe, A. - Willis, P. (szerk.): Culture, media, language. Working papers in cultural studies 1972-79. London, Routledge, 66-75.

Cohen, S. (1972): Folk devils and moral panics. The creation of mods and rockers. London, Routledge.

Erikson, E. H. (1950): Childhood and society. Norton, New York. https://www.doi.org/10.1126/science.113.2931.253

Geertz, C. (2001a): „A bennszülöttek szemszögéből”. Az antropológiai megértés természetéről. In: Geertz, C. (szerk.): Az értelmezés hatalma. Antropológiai írások. Osiris, Budapest, 227-245.

Geertz, C. (2001b) Sűrű leírás. Út a kultúra értelmező elméletéhez. In: Geertz, C. (szerk): Az értelmezés hatalma. Antropológiai írások. Osiris, Budapest, 194-226.

Gelder, K. (2005): The field of subcultural studies. In: Gelder, K. (szerk.) The subcultures reader. London, Routledge, 1-15.

Gyenge E. (2014): Krízisek gyermek- és serdülőkorban. In: Vörös V. - Osváth P. - Árkovits A. - Csürke J. (szerk.): Mindennapi kríziseink. A lélektani krízis és a krízisintervenció kézikönyve. Oriold, Budapest, 171-185.

Haenfler, R. (2013): Subcultures. The basics. London, Routledge. https://doi.org/10.4324/9781315888514

Hajduska M. (2015): Krízislélektan. ELTE Eötvös Kiadó, Budapest.

Hall, S. (1996): Introduction: Who needs 'identity'? In: Hall, S. - du Gay, P. (szerk.): Questions of cultural identity. Sage, London, 1-17. https://doi.org/10.4135/9781446221907.n1

Hebdige, D. (1979): Subculture. The meaning of style. London, Routledge. https://doi.org/10.4324/9780203139943

Hodkinson, P. (2002): Goth. Identity, style and subculture. Berg, Oxford. https://doi.org/10.1017/S0261143004280254

Holmes, T. H. - Rahe, R. H. (1967): The social readjustment rating scale. Journal of psychosomatic research, 11(2): 213-218. https://doi.org/10.1016/0022-3999(67)90010-4

Horányi Ö. (1999): A kommunikációról. In: Béres I. - Horányi Ö. (szerk.): Társadalmi kommunikáció. Budapest, Osiris, 22-34.

Horányi Ö. (2007): A kommunikáció participációra alapozott felfogásáról. In: Horányi Ö. (szerk.): A kommunikáció mint participáció. AKTI - Typotex, Budapest, 246-264. 


\section{KÖZELKÉP - Tanulmányok}

Jacobson, G. F. (1979): Crisis-oriented therapy. Symposium on brief psychotherapy. Psychiatric clinics of North America, 2(1): 39-54.

Linehan, M. M. (2010): A borderline személyiségzavar kognitív viselkedésterápiája. Budapest, Medicina.

Martin, J. - Nakayama, T. - Carbaugh, D. (2012): The history and development of the study of intercultural communication, and applied linguistics. In: Jackson, J. (szerk.): The Routledge handbook of language and intercultural communication. Routledge, Abingdon, 17-36. https://www.doi.org/10.4324/9780203805640

Mészáros Gy. (2017): Pedagógiai etnográfia. Budapest, ELTE Eötvös Kiadó.

Muggleton, D. (2002): Inside subculture. The postmodern meaning of style. Oxford, Berg, http://dx.doi.org/10.5040/9781474214988

Pete, K. - P. Szilczl, D. (2007) A kommunikáció intézményeiről. In: Horányi Ö. (szerk.): A kommunikáció mint participáció. Budapest, AKTI - Typotex, 17-100.

Philips, S. U. (2005): A comparison of Indian and Anglo communicative behavior in classroom interaction. In: Kiesling, S. F. - Paulston, C. B. (szerk.): Intercultural discourse and communication. The essential readings. Blackwell Publishing, Malden, 291-303. https://doi.org/10.1002/9780470758434.ch19

Rácz J. (1998): A '80-as évek ifjúsági szubkultúrái Magyarországon. In: Rácz J. (szerk.): Ifjúsági (szub)kultúrák, intézmények, devianciák. Válogatott tanulmányok. Scientia Humana, Budapest, 51-69.

Rill, B. (2006): Rave, communitas, and embodied idealism. Music therapy today, 7(3): 648-661.

Rohrer, I. (2014): Cohesion and dissolution. Friendship in the globalized punk and hardcore scene of Buenos Aires. Springer, Wiesbaden. https://doi.org/10.1007/978-3-658-04360-5

Shannon, C. E. (1986): A hírközlés matematikai elmélete. In: Shannon, C. E. - Weaver, Warren (szerk.): A kommunikáció matematikai elmélete. Az információelmélet születése és távlatai. Országos Műszaki Információs Központ és Könyvtár, Budapest, 43-152.

Szentesi B. (2013): A (szub)kulturális kategorizáció mint pedagógiai eszköz. Egy alternatív középiskola belső diskurzusai kulturális és kommunikációs megközelítésben. In: Szász A. - Kirzsa F. (szerk.): Kultúrakutatás és narratíva. Tanulmánykötet A. Gergely András tiszteletére 60. születésnapja alkalmából. MAKAT L'Harmattan, Budapest, 296-310.

Szentesi B. (2018): A belső pozíció haszna. A saját közösség kutatásának tapasztalatai. Kultúra és közösség, 9(4): 89-101. 


\section{KÖZELKÉP - Tanulmányok}

Szentesi B. (2019): Másság és alkudozás. Az érvénytelenség problémájának megoldása egy alternatív gimnáziumban. Jel-kép, 40(1): 1-15. https://www.doi.org/10.20520/JEL-KEP.2019.1.1

Thornton, S. (1995): Club cultures. Music, media and subcultural capital. Cambridge, Polity.

Turner, V. (2002): A rituális folyamat. Struktúra és antistruktúra. A Rochesteri Egyetemen (Rochester, NewYork) 1966-ban tartott Lewis Henry Morgan-előadások. Budapest, Osiris.

van Gennep, A. (2007): Átmeneti rítusok. MTA Néprajzi Kutatóintézete - PTE Néprajz - Kulturális Antropológia Tanszék - L'Harmattan, Budapest - Pécs.

Watzlawick, P. - Beavin, J. H. - Jackson, D. D. (2009): Az emberi érintkezés. Formák, zavarok, paradoxonok. Animula, Budapest.

Weaver, W. (1986): Újabb adalékok a hírközlés matematikai elméletéhez. In: Shannon, C. E. - Weaver, Warren (szerk.): A kommunikáció matematikai elmélete. Az információelmélet születése és távlatai. Országos Műszaki Információs Központ és Könyvtár, Budapest, 11-41. 